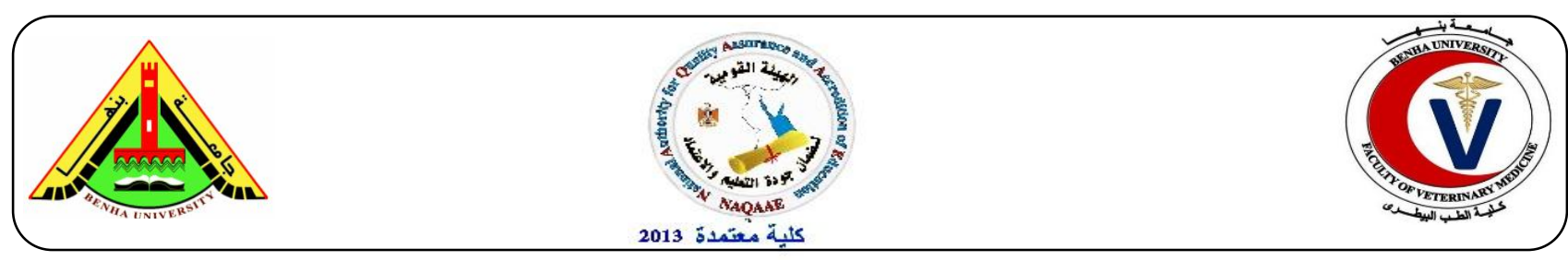

\title{
Effect of Castration on Some Immunological Aspects in Male Albino Rat
}

\author{
Habak S. M., Azab M. E., Ismail, R. S. and Nafeaa, A. A.
}

Physiology Department, Faculty of Veterinary Medicine, Benha University, Egypt

\section{A B S T R A C T}

The current study aimed to evaluate the effect of surgical and chemical castration on some immunological aspects in adult male albino rats. A total number of forty adult male albino rats weighing $220 \pm 20 \mathrm{~g}$ and averaging 4 months old were used. Rats were divided into four equal groups. Group 1, intact control group; group 2, sham castrated group; group3, surgically castrated group and group 4, chemically castrated group. Relative thymus and spleen weight, peripheral total and differential leukocytic count and relative expression of TNF $\alpha$ gene were recorded at 2 and 4 weeks after castration. The obtained results revealed that surgical and chemical castration resulted in a significant increase in relative thymus and spleen weight. Peripheral total leukocytic count was significantly increased in surgically and chemically castrated groups as compared to intact control and sham groups. Differential leukocytic count revealed a significant increase in lymphocyte number and a significant decrease in neutrophil number in surgically and chemically castrated groups as compared to intact control and sham groups. Real-time quantitative PCR analysis of $\mathrm{TNF} \alpha$ gene expression in spleen revealed that surgical and chemical castration resulted in significant up regulation of TNF $\alpha$ gene expression. So, it concluded that surgical and chemical castration improved immunity and testosterone has an immunosuppressive effect in adult male albino rats.

Key words: Surgical, Chemical, Castration, Rats, Immunological aspects.

(http://www.bvmj.bu.edu.eg)

(BVMJ-35(1): 76-83, 2018)

\section{INTRODUCTION}

Immune system does not work in isolation as immune, endocrine and central nervous systems are integrated through a network of signal molecules (cytokines, hormones and neurotransmitters) that act on a common set of receptors. It is influenced by many other factors that may be neuroendocrine peptides, sex hormones or other metabolites (Bhatia et al., 2014). Androgens play a very important role in modulating the immune system by affecting the innate as well as the adaptive immune system, both at the developmental and functional levels. Androgens are generally immunosuppressive targeting many arms of the immune system and act to inhibit the immune response (Trigunaite et al., 2015). The decline in immune function with aging represents a major clinical challenge in many disease conditions. It is obvious in many parameters but is essentially linked to the adaptive immune responses. The prediction would be that abnormalities in both $\mathrm{T}$ and $\mathrm{B}$ lymphocytes underlie the loss of cellular and humoral capacity, respectively. There is a major reduction in naïve $\mathrm{T}$ cells with a proportional increase in memory cells, in addition to a generally reduced function of these cells. While bone marrow function 
reduces with age, the most obvious reason for the $\mathrm{T}$ cell defects is the severe atrophy of the thymus (Calder et al., 2011).

The thymus is known to be acutely sensitive to sex steroids and similar lines of correlative evidence have strongly linked changes in sex steroid levels, especially androgens, to thymic degeneration with age. Notably, the greatest rate of thymic involution with age is observed at puberty, thereby implicating a major role for sex steroids in both thymus and immune system deterioration with age (Majumdar and Nandi, 2018). Accordingly, surgical or chemical castration (by using LHRH agonist) blocks sex steroids resulting in profound rejuvenation of the immune system. Surgical or chemical castration reverses age-related thymic atrophy and restores thymic function with a decrease in the rate of thymocyte apoptosis and increased proliferation of both $\mathrm{T}$ cells and thymic epithelial cells (Safadi et al., 2000; Sutherland et al., 2005) and improves lymphocyte recovery following hematopoietic stem cell transplantation (HSCT) and chemotherapy (Goldberg et al., 2007) while the re-administration of androgen prevents this reconstitution (Azad et al., 1998).

The current study aimed to evaluate the effect of surgical and chemical castration on some immunological aspects in adult male albino rats.

\section{MATERIALS AND METHODS}

\subsection{Experimental design}

A total number of 40 adult albino male rats weighing $220 \pm 20 \mathrm{~g}$ and averaging 4 months old were obtained from laboratory animal unit in Faculty of Veterinary Medicine, Benha University. Rats were housed in separate wire mesh cages, under standard laboratory conditions (temperature at $24 \pm 2 \mathrm{C}^{0}$, good ventilation, humidity and

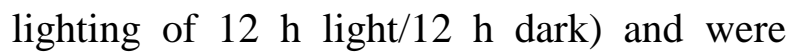
allowed ad libitum access to food and fresh water. The animals were divided into 4 groups with 10 rats in each. Group 1, intact control group, group 2, sham castrated group, group 3, surgically castrated group and group 4 , chemically castrated group.

\subsection{Surgical castration}

Rats were anesthetized by injection of ketamine and xylazine at a dose of $75 \mathrm{mg} / \mathrm{kg}$ and $5 \mathrm{mg} / \mathrm{kg}$ respectively intraperitoneal (Shekarforoush et al., 2016). A single prescrotal incision was made. The spermatic cord was clamped, ligated with dissolvable sutures and the testicles were removed (Miwa and Sladky, 2016).

\subsection{Sham castration}

Sham castration was performed using the same surgical procedure, but without removal of the testes.

2.4 Chemical castration

Lupron ${ }^{\circledR}$ depot, 1-mo depot preparation, (leuprolide acetate, $3.75 \mathrm{mg}$ ) was provided from Takeda Pharmaceutical (Osaka, Japan). Lupron ${ }^{\circledR}$ depot was given as a single subcutaneous injection at a dose of 30 $\mathrm{mg} / \mathrm{kg}$ body weight according to Okada et al. (1991).

2.5 Determination of relative thymus and spleen weights (\% of body weight)

Immediately prior to euthanasia, terminal body weights were collected from 5 rats of each group at 2 and 4 weeks after castration. After euthanasia, the spleen and thymus were quickly excised, freed from extraneous tissue, rinsed in ice-cold saline to clear them of blood and weighed. Relative thymus and spleen weight were measured as percentage of total body weight according to Naninck et al. (2015).

2.6 Determination of peripheral total and differential leukocytic count

Blood samples were collected from retro-orbital venous plexus with EDTA. Total leukocytic count was performed using an improved Neubauer hemocytometer and turkey's solution as a diluent. Differential 
leukocytic count was performed by counting 200 cells in thin homogenous blood film stained by Giemsa stain and the absolute count was calculated (Voigt and Swist, 2011).

2.7 Determination of the relative expression of $T N F \alpha$ gene in spleen

Spleen samples were harvested and immediately put in liquid nitrogen and stored at $-80^{\circ} \mathrm{C}$ till RNA extraction. Pure RNA was extracted using total RNA Purification Kit following the manufacturer protocol (Thermo Scientific, Fermentas, \#K0731). The cDNA was synthesized with the (Thermo Scientific, Fermentas, \#EP0451) kit following the manufacturer's instructions. The isolated cDNA was amplified using $2 \mathrm{X}$ Maxima SYBR Green/ROX qPCR Master Mix (Thermo scientific, USA, \# K0221) and gene Table (1): Oligonucleotide primers sequence for $T N F \alpha$ gene

Forward primer ('5 ------ 3 )

GCATGATCCGCGACGTGGAA

Reverse primer ('5 ------ 3$)$

AGATCCATGCCGTTGGCCAG

\section{RESULTS}

3.1 Effect of castration on relative thymus and spleen weights

The obtained results revealed significant $(\mathrm{P} \leq 0.05)$ increases in relative thymus and spleen weights in surgically and chemically castrated groups as compared to intact control and sham groups (table 2). However, no significant differences were observed either between surgically and chemically castrated groups or between intact control and sham groups.

3.2 Effect of castration on peripheral total and differential leukocytic count

The obtained results revealed significant $(\mathrm{P} \leq 0.05)$ increases in peripheral total leukocytic count and lymphocyte number but significant $(\mathrm{P} \leq 0.05)$ decreases in neutrophil number in surgically and chemically castrated specific primers. The primers used in the amplification are shown in table (1). The final reaction mixture was placed in a Piko real time thermal cycler (Thermo Scientific, Life technology, USA). The quantities critical threshold $(\mathrm{Ct})$ of target gene were normalized with quantities $(\mathrm{Ct})$ of $\beta$-actin by used the 2 $\Delta \Delta \mathrm{Ct}$ method (Livak and Schmittgen, 2001)

2.8 Statistical analysis

All the data were statistically evaluated with SPSS/11 software.2011 Hypothesis testing methods included one way analysis of variance (ANOVA). $\mathrm{P}$ values of less than 0.05 were considered to indicate statistical significance. All the results were expressed as mean \pm SEM for five animals in each group. 
Table (2): Effect of castration on relative thymic and spleen weights at 2 and 4 weeks after castration (means \pm SEM)

\begin{tabular}{|c|c|c|c|c|}
\hline \multirow[t]{2}{*}{ Parameter } & \multicolumn{2}{|c|}{$\begin{array}{l}\text { Relative thymic weight } \\
\qquad(\% \text { of } \mathrm{BW})\end{array}$} & \multicolumn{2}{|c|}{$\begin{array}{l}\text { Relative spleen weight } \\
(\% \text { of } \mathrm{BW})\end{array}$} \\
\hline & 2 weeks & 4 weeks & 2 weeks & 4 weeks \\
\hline Intact control & $0.38^{b} \pm 0.01$ & $0.41^{b} \pm 0.02$ & $0.26^{b} \pm 0.02$ & $0.31^{b} \pm 0.01$ \\
\hline Sham & $0.34^{b} \pm 0.02$ & $0.42^{b} \pm 0.01$ & $0.23^{b} \pm 0.03$ & $0.29^{b} \pm 0.02$ \\
\hline Surgically castrated & $0.55^{\mathrm{a}} \pm 0.02$ & $0.52^{\mathrm{a}} \pm 0.03$ & $0.36^{\mathrm{a}} \pm 0.01$ & $0.38^{\mathrm{a}} \pm 0.01$ \\
\hline Chemically castrated & $0.54^{\mathrm{a}} \pm 0.01$ & $0.51^{\mathrm{a}} \pm 0.01$ & $0.38^{\mathrm{a}} \pm 0.01$ & $0.43^{\mathrm{a}} \pm 0.02$ \\
\hline
\end{tabular}

Means within the same column carrying different superscript letters are significantly different at $\mathrm{P} \leq$ 0.05 .

Table (3): Effect of castration on peripheral total leukocytic count at 2 and 4 weeks after castration (means \pm SEM)

Parameter Peripheral total leukocytic count $\left(10^{3} / \mu \mathrm{l}\right)$
Groups
2 weeks
4 weeks
Intact control
$9.13^{\mathrm{b}} \pm 0.55$
$9.34^{\mathrm{b}} \pm 0.54$
Sham
$9.09^{\mathrm{b}} \pm 0.21$
$8.98^{\mathrm{b}} \pm 0.39$
Surgically castrated
$12.06^{\mathrm{a}} \pm 0.54$
$12.11^{\mathrm{a}} \pm 0.72$
Chemically castrated
$11.55^{\mathrm{a}} \pm 0.48$
$11.79^{\mathrm{a}} \pm 0.64$

Means within the same column carrying different superscript letters are significantly different at $\mathrm{P} \leq$ 0.05 . 
Table 4: Effect of castration on differential leukocytic count at 2 and 4 weeks after castration (means \pm SEM)

\begin{tabular}{|c|c|c|c|c|c|c|c|c|c|c|}
\hline \multirow[b]{2}{*}{ Parameter } & \multicolumn{10}{|c|}{ Differential leukocytic count } \\
\hline & \multicolumn{2}{|c|}{$\begin{array}{l}\text { Lymphocytes } \\
\qquad\left(10^{3} / \mu \mathrm{l}\right)\end{array}$} & \multicolumn{2}{|c|}{$\begin{array}{c}\text { Neutrophils } \\
\left(10^{3} / \mu \mathrm{l}\right)\end{array}$} & \multicolumn{2}{|c|}{$\begin{array}{c}\text { Monocytes } \\
\left(10^{3} / \mu \mathrm{l}\right)\end{array}$} & \multicolumn{2}{|c|}{$\begin{array}{l}\text { Eosinophils } \\
\qquad\left(10^{3} / \mu \mathrm{l}\right)\end{array}$} & \multicolumn{2}{|c|}{$\begin{array}{l}\text { Basophils } \\
\left(10^{3} / \mu \mathrm{l}\right)\end{array}$} \\
\hline Groups & $\begin{array}{c}2 \\
\text { weeks }\end{array}$ & $\begin{array}{c}4 \\
\text { weeks }\end{array}$ & $\begin{array}{c}2 \\
\text { weeks }\end{array}$ & $\begin{array}{c}4 \\
\text { weeks }\end{array}$ & $\begin{array}{c}2 \\
\text { weeks }\end{array}$ & $\begin{array}{c}4 \\
\text { weeks }\end{array}$ & $\begin{array}{c}2 \\
\text { weeks }\end{array}$ & $\begin{array}{c}4 \\
\text { weeks }\end{array}$ & $\begin{array}{c}2 \\
\text { weeks }\end{array}$ & $\begin{array}{c}4 \\
\text { weeks }\end{array}$ \\
\hline Intact control & $\begin{array}{c}5.3 \cdot b \\
\pm \\
0.23\end{array}$ & $\begin{array}{c}4.54^{\mathrm{b}} \pm \\
0.58\end{array}$ & $\begin{array}{c}3.28^{\mathrm{a}} \pm \\
0.17\end{array}$ & $\begin{array}{c}3.61^{\mathrm{a}} \pm \\
0.1^{.}\end{array}$ & $\begin{array}{c}0.42^{\mathrm{a}} \pm \\
0.03\end{array}$ & $\begin{array}{c}0.49^{\mathrm{a}} \pm \\
0.06\end{array}$ & $\begin{array}{c}0.25^{\mathrm{a}} \pm \\
0.06\end{array}$ & $\begin{array}{c}0.61^{\mathrm{a}} \pm \\
0.34\end{array}$ & $\begin{array}{c}0.00 \pm \\
0.00\end{array}$ & $\begin{array}{c}0.00 \pm \\
0.00\end{array}$ \\
\hline Sham & $\begin{array}{c}5.1 \cdot b \\
\pm \\
0.42\end{array}$ & $\begin{array}{c}4.67^{\mathrm{b}} \pm \\
0.68\end{array}$ & $\begin{array}{c}3.27^{\mathrm{a}} \pm \\
0.19\end{array}$ & $\begin{array}{c}3.55^{\mathrm{a}} \pm \\
0.25\end{array}$ & $\begin{array}{c}0.48^{\mathrm{a}} \pm \\
0.09\end{array}$ & $\begin{array}{c}0.29^{\mathrm{a}} \pm \\
0.03\end{array}$ & $\begin{array}{c}0.31^{\mathrm{a}} \pm \\
0.03\end{array}$ & $\begin{array}{c}0.38^{\mathrm{a}} \pm \\
0.14\end{array}$ & $\begin{array}{c}0.00 \pm \\
0.00\end{array}$ & $\begin{array}{c}0.00 \pm \\
0.00\end{array}$ \\
\hline Surgically castrated & $\begin{array}{c}8.59^{\mathrm{a}} \\
\pm \\
0.57\end{array}$ & $\begin{array}{c}8.53^{\mathrm{a}} \pm \\
0.48\end{array}$ & $\begin{array}{c}1.91^{\mathrm{b}} \pm \\
0.14\end{array}$ & $\begin{array}{c}2.43^{b} \pm \\
0.23\end{array}$ & $\begin{array}{c}0.68^{\mathrm{a}} \pm \\
0.11\end{array}$ & $\begin{array}{c}0.48^{\mathrm{a}} \pm \\
0.08\end{array}$ & $\begin{array}{c}0.25^{\mathrm{a}} \pm \\
0.09\end{array}$ & $\begin{array}{c}0.32^{\mathrm{a}} \pm \\
0.09\end{array}$ & $\begin{array}{c}0.00 \pm \\
0.00\end{array}$ & $\begin{array}{c}0.00 \pm \\
0.00\end{array}$ \\
\hline Chemically castrated & $\begin{array}{c}8.46^{\mathrm{a}} \\
\pm \\
0.41\end{array}$ & $\begin{array}{c}8.69^{\mathrm{a}} \pm \\
0.38\end{array}$ & $\begin{array}{c}1.82^{b} \pm \\
0.27\end{array}$ & $\begin{array}{c}2.27^{\mathrm{b}} \pm \\
0.18\end{array}$ & $\begin{array}{c}0.69^{\mathrm{a}} \pm \\
0.08\end{array}$ & $\begin{array}{c}0.31^{\mathrm{a}} \pm \\
0.03\end{array}$ & $\begin{array}{c}0.37^{\mathrm{a}} \pm \\
0.08\end{array}$ & $\begin{array}{c}0.27^{\mathrm{a}} \pm \\
0.06\end{array}$ & $\begin{array}{c}0.00 \pm \\
0.00\end{array}$ & $\begin{array}{c}0.00 \pm \\
0.00\end{array}$ \\
\hline
\end{tabular}

Means within the same column carrying different superscript letters are significantly different at $\mathrm{P} \leq$ 0.05 .

Table (5): Effect of castration on relative expression of TNFa gene in spleen at 2 and 4 weeks after castration (means \pm SEM)

\section{Parameter}

Groups

Intact control

Sham

Surgically castrated

Chemically castrated

$$
2 \text { weeks }
$$

$$
1.00^{c} \pm 0.05
$$$$
1.32^{c} \pm 0.15
$$$$
11.96^{\mathrm{a}} \pm 0.43
$$

$8.75^{\mathrm{b}} \pm 0.31$

\section{Fold change}

\section{4 weeks}

$1.00^{\mathrm{c}} \pm 0.05$

$1.15^{\mathrm{c}} \pm 0.07$

$5.06^{\mathrm{a}} \pm 0.28$

$3.43^{\mathrm{b}} \pm 0.16$

Means within the same column carrying different superscript letters are significantly different at $\mathrm{P} \leq$ 0.05 .

\section{DISCUSSION}

The results described in the present study showed that both surgical and chemical castration caused significant increase in relative thymus and spleen weight in postpubertal male rats as compared to intact

controls and sham castrated rats. These results are consistent with the results obtained by Dorko et al. (2011) who reported that both surgical and chemical castration resulted in increase in thymus weight in postpubertal 
male rats. Similarly, previous study in postpubertal male mice by Roden et al. (2004) showed that surgical castration resulted in hyperplasia of the thymus, spleen, and lymph nodes which appears 2 weeks after castration. They extended these observations further by showing that castration-induced peripheral lymph node hyperplasia occurs primarily due to a trebling of both $\mathrm{B} 220^{+}$and $\mathrm{CD}^{+}$cell levels within nodal tissues.

Sutherland et al. (2005) reported that castration has a stimulating effect on the precursor stem cell population in the bone marrow. In addition, they observed that castration induced a rapid restoration of thymopoiesis, with significantly enhanced proliferation and reduced apoptosis evident by 1week postcastration. Thus, the observed increase in relative thymus weight after castration may be due to improved precursor generation in the bone marrow, enhanced proliferation and reduced apoptosis of thymocytes.

Androgen ablation resulted in significant increases in the relative number of IL-7responsive $\mathrm{B}$ cell progenitors in the bone marrow (Ellis et al., 2001). Thus, the observed increase in relative spleen weight after castration may be attributed largely to the significant increases in the number of recent bone marrow emigrated B cells.

Regarding to peripheral total leukocytic count, the obtained results revealed that surgical and chemical castration of adult male rats resulted in significant increase in peripheral total leukocytic count. These results support the previous findings of Ellis et al., (2001) who recorded that castration of adult male mice caused a significant increase in the number of peripheral blood leukocytes. Also, Umathe et al. (2008) reported that leuprolide acetate administration to adult mice caused a significant increase in total leukocytic count. The observed increase in peripheral total leukocytic count is mainly due to the increase in lymphocyte number seen in the present study.

Regarding to differential leukocytic count, the present study showed a significant increase in peripheral lymphocyte number and a significant decrease in peripheral neutrophil number in surgically and chemically castrated groups as compared to intact control and sham groups. These results are consistent with the results obtained by Lai et al. (2012) who showed that castration of male mice caused reduction in neutrophil counts and a significant increase in lymphocytes. Similarly, previous study of Sutherland et al. (2008) showed that LHRH agonist administration in human male prior to stem cell transplantation resulted in a significant increase in lymphocyte numbers and, in contrast to the present study, a significant increase in neutrophils numbers within the first month of post transplantation.

Neutrophils possess high levels of androgen receptors as reported by Trigunaite et al. (2015). And so, the suppressive effect of androgens on neutrophil number was may be explained to be mediated through the androgen receptors.

Androgen has a suppressive effect on development and proliferation of $\mathrm{T}$ and $\mathrm{B}$ cells (Trigunaite et al., 2015). This could explain the observed increase in lymphocyte number seen after castration. As, androgen ablation resulted in removal of the suppressive effects of androgen on development and proliferation of $\mathrm{T}$ and $\mathrm{B}$ cells leading to thymic and splenic enlargement and excessive export of $\mathrm{B}$ and $\mathrm{T}$ lymphocytes.

Regarding to TNFa gene, the obtained results revealed a significant up regulation of $\mathrm{TNF} \alpha$ gene expression level in the spleen of surgically and chemically castrated groups as compared to the intact control and sham groups. Surgically castrated group showed higher expression of $\mathrm{TNF} \alpha$ gene compared to 
and chemically castrated group. These observations were nearly similar with the findings of Chin and Nirwana, (2017) who reported that orchidectomy induced a significant increase in TNF $\alpha$, and IL- $1 \beta$ in adult male rats. Similarly, Klein et al. (2010) found that men with androgen deficiencies have higher levels of IL- $1 \beta$ and TNF- $\alpha$.

Testosterone and dihydrotestosterone have a suppressive effect on $\mathrm{T}$ lymphocytes and so, suppress the pro-inflammatory cytokines produced by these cells as TNF $\alpha / \beta$. Thus, the observed up regulation of TNF $\alpha$ gene expression after castration could be explained by removal of this suppressive effect. So, it concluded that surgical and chemical castration improved immunity and testosterone has an immunosuppressive effect in adult male albino rats.

\section{REFERENCES}

Azad, N., LaPaglia, N., Agrawal, L., Steiner, J., Uddin, S., Williams, D. W., Lawrence, A. M. \& Emanuele, N. V. (1998). The role of gonadectomy and testosterone replacement on thymic luteinizing hormone-releasing hormone production. Journal of Endocrinology, 158(2), 229-235.

Bhatia, A., Sekhon, H. K. \& Kaur, G. (2014). Sex hormones and immune dimorphism. Scientific World Journal, 2014: 1-8.

Calder, A. E., Hince, M. N., Dudakov, J. A., Chidgey, A. P. \& Boyd, R. L. (2011). Thymic involution: Where endocrinology meets immunology. NeuroImmunoModulation, 18(5), 281289.

Chin, K. Y. \& Ima-Nirwana, S. (2017). The effects of testosterone deficiency and its replacement on inflammatory markers in rats: A pilot study. International Journal of Endocrinology and Metabolism, 15(1), 1-5.
Dorko, F., Kluchová, D., Boleková, A., Špakovská, T., Borošová, T. \& Lovasová K. (2011). Influence of surgical and chemical orchidectomy on weight and distribution of AChE-nerve fibres in thymuses of adult rats. European Journal of Histochemistry, 55(22), 117-121.

Ellis, T. M., Moser, M. T., Le, P. T., Flanigan, R. C. \& Kwon, E. D. (2001). Alterations in peripheral B cells and B cell progenitors following androgen ablation in mice. International Immunology, 13(4), 553-558.

Goldberg, G. L., Alpdogan, O., Muriglan, S. J., Hammett, M. V., Milton, M. K., Eng, J. M., Hubbard, V. M., Kochman, A., Willis, L. M., Greenberg, A. S., Tjoe, K. H., Sutherland, J. S., Chidgey, A., Brink, M. R. M. V. D. \& Boyd, R. L. (2007). Enhanced immune reconstitution by sex steroid ablation following allogeneic hemopoietic stem cell transplantation. The Journal of Immunology, 178(11), 7473-7484.

Klein, S. L., Jedlicka, A. \& Pekosz, A. (2010). The Xs and Y of immune responses to viral vaccines. The Lancet Infectious Diseases, 10(5), 338-349.

Lai, J.-J., Lai, K.-P., Zeng, W., Chuang, K.H., Altuwaijri, S. \& Chang, C. (2012). Androgen receptor influences on body defense system via modulation of innate and adaptive immune systems: lessons from conditional AR knockout mice. The American Journal of Pathology, 181(5), 1504-1512.

Livak, K. J. \& Schmittgen, T. D. (2001). Analysis of Relative Gene Expression Data Using Real-Time Quantitative PCR and the 2- $\Delta \Delta \mathrm{CT}$ Method. Methods, 25(4), 402-408.

Majumdar, S. \& Nandi, D. (2018). Thymic Atrophy: Experimental Studies and Therapeutic Interventions. Scandinavian Journal of Immunology, 87(1), 4-14. 
Miwa, Y. \& Sladky, K. K. (2016). Small mammals: common surgical procedures of rodents, ferrets, hedgehogs, and sugar gliders. Veterinary Clinics of North America - Exotic Animal Practice, 19(1), 205-244.

Naninck, E. F. G., Hoeijmakers, L., KakavaGeorgiadou, N., Meesters, A., Lazic, S. E., Lucassen, P. J. \& Korosi, A. (2015). Chronic Early Life Stress Alters Developmental and Adult Neurogenesis and Impairs Cognitive Function in Mice. HIPPOCAMPUS, 25, 309-328.

Okada, H., Heya, T., Ogawa, Y., Toguchi, H. \& Shimamoto, T. (1991). Sustained pharmacological activities in rats following single and repeated administration of once-a-month injectable microspheres of leuprolide acetate. Pharmaceutical Research, 8(5), 584-587.

Roden, A. C., Moser, M. T., Tri, S. D., Mercader, M., Kuntz, S. M., Dong, H., Hurwitz, A. A., McKean, D. J., Celis, E., Leibovich, B. C., Allison, J. P. \& Kwon, E. D. (2004). Augmentation of T Cell Levels and Responses Induced by Androgen Deprivation. The Journal of Immunology, 173(10), 6098-6108.

Safadi, F. F., Dissanayake, I. R., Goodman, G. G., Jago, R. A., Baker, A. E., Bowman, A. R., Sass, D. A., Popoff, S. N. $\&$ Epstein, S. (2000). Influence of estrogen deficiency and replacement on T-cell populations in rat lymphoid tissues and organs. Endocrine, 12(1), 8188.

Shekarforoush, S., Fatahi, Z. \& Safari, F. (2016). The effects of pentobarbital, ketamine-pentobarbital and ketaminexylazine anesthesia in a rat myocardial ischemic reperfusion injury model. Laboratory Animals, 50(3), 179-184.

Sutherland, J. S., Goldberg, G. L., Hammett, M. V., Uldrich, A. P., Berzins, S. P.,
Heng, T. S., Blazar, B. R., Millar, J. L., Malin, M. A., Chidgey, A. P. \& Boyd, R. L. (2005). Activation of Thymic Regeneration in Mice and Humans following Androgen Blockade. The Journal of Immunology, 175(4), 27412753.

Sutherland, J. S., Spyroglou, L., Muirhead, J. L., Heng, T. S., Prieto-Hinojosa, A., Prince, H. M., Chidgey, A. P., Schwarer, A. P. \& Boyd, R. L. (2008). Enhanced immune system regeneration in humans following allogeneic or autologous hemopoietic stem cell transplantation by temporary sex steroid blockade. Clinical Cancer Research, 14(4), 1138-1149.

Trigunaite, A., Dimo, J. \& Jørgensen, T. N. (2015). Suppressive effects of androgens on the immune system. Cellular Immunology, 294(2), 87-94.

Umathe, S. N., Dixit, P. V., Wanjari, M. M. \& Ullewar, M. P. (2008). Leuprolide -a GnRH agonist prevents restraint stressinduced immunosuppression via sex steroid-independent peripheral mechanism in mice. International Immunopharmacology, 8(1), 71-79.

Voigt, G. L. \& Swist, S. L. (2011). Hematology techniques and concepts for veterinary technicians. $2^{\text {nd }}$ Ed. A John Wiley and Sons. 